\title{
Grazing height targets for Alexandergrass pastures under continuous stocking in integrated crop-livestock system
}

\author{
André Brugnara Soares ${ }^{1}$ (D) Daniel Schmitt ${ }^{{ }^{*}}$ (D) Francisco Migliorini $^{1}$ (D) \\ Tangriani Simioni Assmann ${ }^{1}$ (i) Alceu Luís Assmann² ${ }^{\text {(D) }}$
}

${ }^{1}$ Universidade Tecnológica Federal do Paraná (UTFPR), 85503-390, Pato Branco, PR, Brasil. E-mail: daniel.schmitt@veterinario.med.br. "Corresponding author.

${ }^{2}$ Instituto Agronômico do Paraná (IAPAR), Pato Branco, PR, Brasil.

ABSTRACT: The aim of this experiment was to identify grazing height targets for Alexandergrass pastures under continuous stocking in integrated crop-livestock system (ICLS). For this purpose, twelve pastures were cultivated into an ICLS area, and maintained at 10, 20, 30, or $40 \mathrm{~cm}$ using grazing goats. The following variables were analyzed: leaf and herbage mass, accumulation rate, and allowance; leaf:stem ratio; chemical composition of hand-plucked samples; stocking rate; average daily gain and gain per area. The data were submitted to regression and correlation analysis. Significance was set at $5 \%(P \leq 0.05)$. The main results were: $i)$ herbage and leaf lamina mass increased linearly with grazing height, and pastures maintained at $20 \mathrm{~cm}$ already presented the minimum amount recommended for soil cover in ICLS; ii) animal performance achieved an upper asymptotic plateau in pastures maintained around $30-40 \mathrm{~cm}$ and it was highly correlated with both grazing height and forage availability (mass and allowance). Alexandergrass pastures under continuous stocking in ICLS should be maintained between 30-40 cm to improve both cover crop biomass and animal performance.

Key words: crop rotation, grazing intensity, goats, Urochloa plantaginea.

Alturas de manejo para pastos de papuã sob lotação contínua em sistema de integração lavoura-pecuária

RESUMO: O objetivo deste trabalho foi identificar alturas de manejo para pastos de papuã sob lotação contínua em sistemas de integração lavoura-pecuária (ILP). Para tanto, doze pastos foram cultivados em uma área de ILP e mantidos em 10, 20 , 30 ou $40 \mathrm{~cm}$ por meio de lotação contínua com caprinos. As seguintes variáveis foram analisadas: massa; taxa de acúmulo e oferta de forragem e de folhas; relação lâmina:colmo; composição química de amostras de simulação de pastejo; carga animal; ganho médio diário e produção animal por área. Os dados foram submetidos a análises de regressão e correlação. A significância adotada foi de $5 \%(P \leq 0,05)$. Os principais resultados foram: $i)$ houve um aumento linear na massa de forragem e folhas com o aumento da altura de manejo e pastos com mais de $20 \mathrm{~cm}$ já apresentavam a quantidade mínima recomendada para cobertura de solo em ILP ii) o desempenho animal atingiu um platô assintótico nos pastos manejados entre 30-40 cm e foi altamente correlacionado com a altura de manejo e a disponibilidade de forragem (massa e oferta). Pastos de Papuã manejados sob lotação contínua em ILP devem ser mantidos entre 30-40 cm para favorecer a produção de biomassa de cobertura e o desempenho animal.

Palavras-chave: caprinos, intensidade de pastejo, rotação de culturas, Urochloa plantaginea.

\section{INTRODUCTION}

Alexandergrass (Urochloa [Syn. Brachiaria] plantaginea), popularly known in Brazil as 'Papuã', is an annual warm-season grass that growths spontaneously in grain crop fields during the late spring and summer (RESTLE et al., 2002). In areas devoted to integrated crop-livestock systems (ICLS), it can be a low-cost forage alternative, since it presents high levels of herbage production and is available in large quantities at the end of the summer cropping season (ADAMI et al., 2010). Therefore, Alexandergrass could be used as pasture (NEGRINI et al., 2018), cover crop biomass (BOLLINGER et al., 2006) or stockpiled forage (SILVA et al., 2011), being an interesting alternative for crop rotation planning.

Despite the advantages, Alexandergrass has not been widely used. A possible explanation may be the lack of easily applied and low-cost management tools to maximize forage accumulation and animal 
performance in this pasture. This is because, studies with Alexandergrass have recommended different levels of forage mass (e.g. ADAMI et al., 2010), which is laborious and time-consuming to be used under field situations, and nitrogen fertilization levels (e.g. MARTINS et al., 2000), which is expensive and does not control sward canopy structure (DA SILVA et al., 2015). Moreover, they do not take into account cover crop biomass production, an essential feature in ICLS (DE MORAES et al., 2014).

Studies with warm-season grasses have shown that grazing management targets based on sward canopy heights (an easily and low-cost tool) generate consistent relationships between responses of plants and animals, allowing a good control over forage production and animal performance (DA SILVA et al., 2015). In this sense, pastures under continuous stocking must be maintained within a range of grazing height targets to obtain high productive potential (e.g. CARNEVALLI et al., 2001; DA SILVA et al., 2013). Despite the explanatory bases are well established, there are no conclusive data concerning the optimal grazing height targets for Alexandergrass pastures. Moreover, because diversification is another important concept in ICLS (DE MORAES et al., 2014), studies with goats (a less common animal species in these systems) are still necessary. The aim of this study was to identify grazing height targets for Alexandergrass pastures under continuous stocking in ICLS.

\section{MATERIALS AND METHODS}

Our experiment was conducted in Pato Branco/PR, Brazil $\left(25^{\circ} 07^{\prime} \mathrm{S}, 52^{\circ} 41^{\prime} \mathrm{W}\right)$, between January and April 2010. According to Köppen classification, the region has a Cfa-type climate (humid subtropical) with cold winters, hot summers, and well-distributed rainfall throughout the year. During the experiment, no water deficit was observed (precipitation of 951 $\mathrm{mm}$ ) and the recorded minimum, mean, and maximum temperatures were, respectively, $17.7^{\circ} \mathrm{C}, 22.5^{\circ} \mathrm{C}, 27.3$ ${ }^{\circ} \mathrm{C}$. The experimental site has been historically managed under non-tillage ICLS; the preceding crops were maize (Zea mays L. 'IPR 114') during the summer 2008/2009, and black oats (Avena strigosa Scherb. 'IAPAR 61') intercropped with annual ryegrass (Lolium multiflorum Lam. 'São Gabriel') during the winter 2009. The soil at the site is a Ferritic Ferralsols (FAO, 2014), with clayey texture, and the average soil chemical characteristic at 0-15 cm depth was: $\mathrm{pH}\left(\mathrm{CaCl}_{2}\right), 4.7 ; \mathrm{OM}, 67.2 \mathrm{~g} \mathrm{dm}^{-3}$; P (Mehlich-1), $19.9 \mathrm{mg} \mathrm{dm}^{-3} ; \mathrm{K}, 399.7 \mathrm{cmol} \mathrm{dm}^{-3}$; Ca, 5.4 $\mathrm{cmol}_{\mathrm{c}} \mathrm{dm}^{-3} ; \mathrm{Mg}, 2.7 \mathrm{cmol}_{\mathrm{c}} \mathrm{dm}^{-3} ; \mathrm{H}+\mathrm{Al}, 7.9 \mathrm{cmol}_{\mathrm{c}} \mathrm{dm}^{-3}$; CEC, $16.9 \mathrm{cmol}_{\mathrm{c}} \mathrm{dm}^{-3}$; base saturation, $52.3 \%$. Pastures were established by natural reseeding and received 200 $\mathrm{kg} \mathrm{N} \mathrm{ha}{ }^{-1}$ and $100 \mathrm{~kg} \mathrm{P}_{2} \mathrm{O}_{5}$ ha $^{-1}$ throughout the study.

On December 10, 2009, a mowing at 10-cm stubble height was done to reduce vegetation cover and improve germination of Alexandergrass seeds. From this date, canopy height was monitored at 40 random points per pasture using a sward stick. On December 31, 2009, grazing was initiated, and the stocking rate $(\mathrm{kg}$ $\mathrm{LW} \mathrm{ha} \mathrm{a}^{-1}$ ) adjusted to set the intended grazing heights. On January 6, 2010, the experiment was initiated. Our study lasted 94 days, 10 days to establish the grazing heights and the remainder divided into four 21-days periods. The decision for experimental closing date was due to the necessity of planting winter crops.

The treatments were four grazing heights $(10,20,30$, or $40 \mathrm{~cm})$, generated by continuous stocking and with variable stocking rate (put-and-take). The grazing heights were based on a study of Brachiaria brizantha 'Marandu' (SBRISSIA et al., 2010), because of structural similarities and the scarcity of references for Alexandergrass. Treatments were applied following a completely randomized design with three replications, totaling twelve pastures (experimental units) of 0.0330.059 ha. Pastures were stocked by one-year-old Boer goats (Capra aegagrus hircus), with initial average body weight of $38 \pm 5.3 \mathrm{~kg}$. Three testers were assigned to each pasture; put-and-take animals could be used to adjust stocking rate to maintain grazing height targets. The animals were not fed concentrates, but we provided free access to $4-\mathrm{m}^{2}$ shelters with fresh water and mineral salt offered ad libitum.

At the beginning of each evaluation period, four representative herbage samples (based on visual assessment of mass and height) were clipped at ground level, using $1-\mathrm{m}^{2}$ circular frames and scissors. These samples were taken to the laboratory, separated into morphological components (leaf (lamina), stems (sheaths + stems), and dead material), and dried in a forced draught oven at $65{ }^{\circ} \mathrm{C}$ until constant weight. Finally, they were weighted to estimate herbage mass $\left(\mathrm{kg} \mathrm{DM} \mathrm{ha}{ }^{-1}\right)$, leaf lamina mass ( $\mathrm{kg} \mathrm{DM} \mathrm{ha-1)}$, and leaf: stem ratio. Forage chemical composition was assessed from hand-plucked samples (EUCLIDES et al., 2009). For this purpose, approximately $700 \mathrm{~g}$ of fresh forage were collected simulating animal's harvesting (based on visual assessment) and dried as described above. Afterwards, they were grounded in a Willey mill to pass a 1-mm screen and submitted to near-infrared spectroscopy to estimate crude protein, neutral and acid detergent fiber contents (\% DM).

Herbage accumulation rate was estimated at the beginning of each experimental period, using three exclusion cages (1-m diameter $\mathrm{x} 1-\mathrm{m}$ height) placed on 
representative points (based on visual assessment) of the pasture. At the same time, three samples outside the cages were clipped at ground level

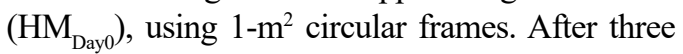
weeks, the herbage inside the cages were collected $\left(\mathrm{HM}_{\text {Day21 } 1}\right)$. All samples were dried as described above. Herbage accumulation rate $\left(\mathrm{kg} \mathrm{DM} \mathrm{ha}^{-1}\right.$ day $^{-1}$ ) was calculated from the difference between herbage mass $\left(\mathrm{HM}_{\text {Day21 }}-\mathrm{HM}_{\text {Day0 }}\right)$ divided by the sampling interval.

Animals were weighed after $16-\mathrm{h}$ food and water fast at the beginning and end of the experiment and every $21 \mathrm{~d}$ in the interim. From these data, we calculated: i) average daily gain ( $g$ LW day $^{-1}$ ), mean variation in testers' live weight during the evaluation period divided by 21 days; ii) stocking rate $\left(\mathrm{kg} \mathrm{LW} \mathrm{ha}{ }^{-1}\right.$ day $\left.^{-1}\right)$, multiplying days in grazing of each animal (tester or put-andtake) by its mean live weight during the evaluation period, summing this product across all animals in the pasture, and then dividing by 21 days; iii) liveweight gain per area ( $\left.\mathrm{kg} \mathrm{LW} \mathrm{ha}^{-1}\right)$, multiplying stocking rate and testers' average daily gain; iv) herbage and leaf lamina allowance $\left(\mathrm{kg} \mathrm{DM} \mathrm{kg} \mathrm{LW}{ }^{-1}\right)$, as proposed by SOLLENBERGER et al (2005).

All data sets were first checked for normality (Shapiro-Wilk test), homogeneity of variance (Levene's mean test), and the presence of outliers (outside \pm 2.5 studentized residuals). Then, they were grouped as the mean of each experimental unit and submitted to regression and correlation analysis. All response variables were plotted against the observed grazing heights. The linear, quadratic, and inverse first-order relationships were considered. If more than one model was significant $(\mathrm{P} \leq 0.05)$, it was decided for that one with higher coefficient of determination $\left(\mathrm{R}^{2}\right)$ and lower root-mean-square error (RMSE). All statistics were performed using SigmaPlot 11.0 (Systat Software, Richmond, CA, USA).

\section{RESULTS AND DISCUSSION}

There were linear increments in herbage $(\mathrm{P}<0.0001)$ and leaf lamina $(\mathrm{P}<0.0001)$ mass according to grazing height increments (Figure 1A and 1B). Herbage $(\mathrm{P}<0.0001)$ and leaf lamina $(\mathrm{P}=0.0038)$ accumulation rate increased quadratically, indicating an apparent stabilization (peaking) at 30-40 cm (Figure 1C and 1D). These responses are in line with the reported for pastures under continuous stocking and are relatively well known for a range of forage plants varying in size/ shapes (DA SILVA et al., 2015). Concerning the values, they were equivalent to that reported for high productive tall-tufted grasses (e.g. Sorghum; RESTLE et al., 2002) or Alexandergrass pastures receiving up to $400 \mathrm{~kg} \mathrm{~N} \mathrm{ha}^{-1}$ (ADAMI et al., 2010); moreover, grazing heights around 20 $\mathrm{cm}$ already presented the minimum amount of herbage mass for a good soil cover in ICLS (2000 kg DM ha ${ }^{-1}$; KUNRATH et al., 2014). Therefore, Alexandergrass pastures under continuous stocking in ICLS should be maintained in more than $20 \mathrm{~cm}$ in order to improve forage and cover biomass production.

There were linear increments in leaf:stem ratio as grazing heights increased $(\mathrm{P}=0.0219$; Figure 2A). The forage chemical composition indicated a slight increase in forage nutritive value as grazing height decreased (i.e. crude protein increased, $\mathrm{P}=0.0346$, Figure $2 \mathrm{~B}$; neutral detergent fiber decreased, $\mathrm{P}=0.0094$, Figure $2 \mathrm{C}$; and acid detergent fiber was constant, $\mathrm{P}=0.8771$, Figure 2D). Such pattern of response can be explained by the greater frequency in which individual plants of intensively grazed swards are defoliated, generating leafier structures with better nutritive value (McCARTHY et al., 2018). Despite such improvements, there were no corresponding increases in average daily gain (described below; Figure 3C), indicating that the variations in animal performance reported in our experiment may not be related to changes in nutritive value. In fact, according to SOLLENBERGER and VANZANT (2011), when pastures present range in forage mass, there may have no relationship between forage nutritive value and average daily gain because of the overriding influence of forage quantity.

There was an inverse first-order relationship between stocking rate and grazing height $(\mathrm{P}=0.0004$; Figure $3 \mathrm{~A})$. Variations in stocking rate are mainly related to variations in herbage production or daily forage intake (HODGSON, 1990); thus, for example, it can be expected greater stocking rates whether herbage production increases or daily forage intake decreases. Because herbage accumulation and stocking rate changed in opposite directions (Figure 2C and Figure 3A), we hypothesized that: i) grazing heights lower than $20 \mathrm{~cm}$ affected daily forage intake (probably via biting constraints) in a greater extent than herbage accumulation rate, demanding more animals to maintain management 


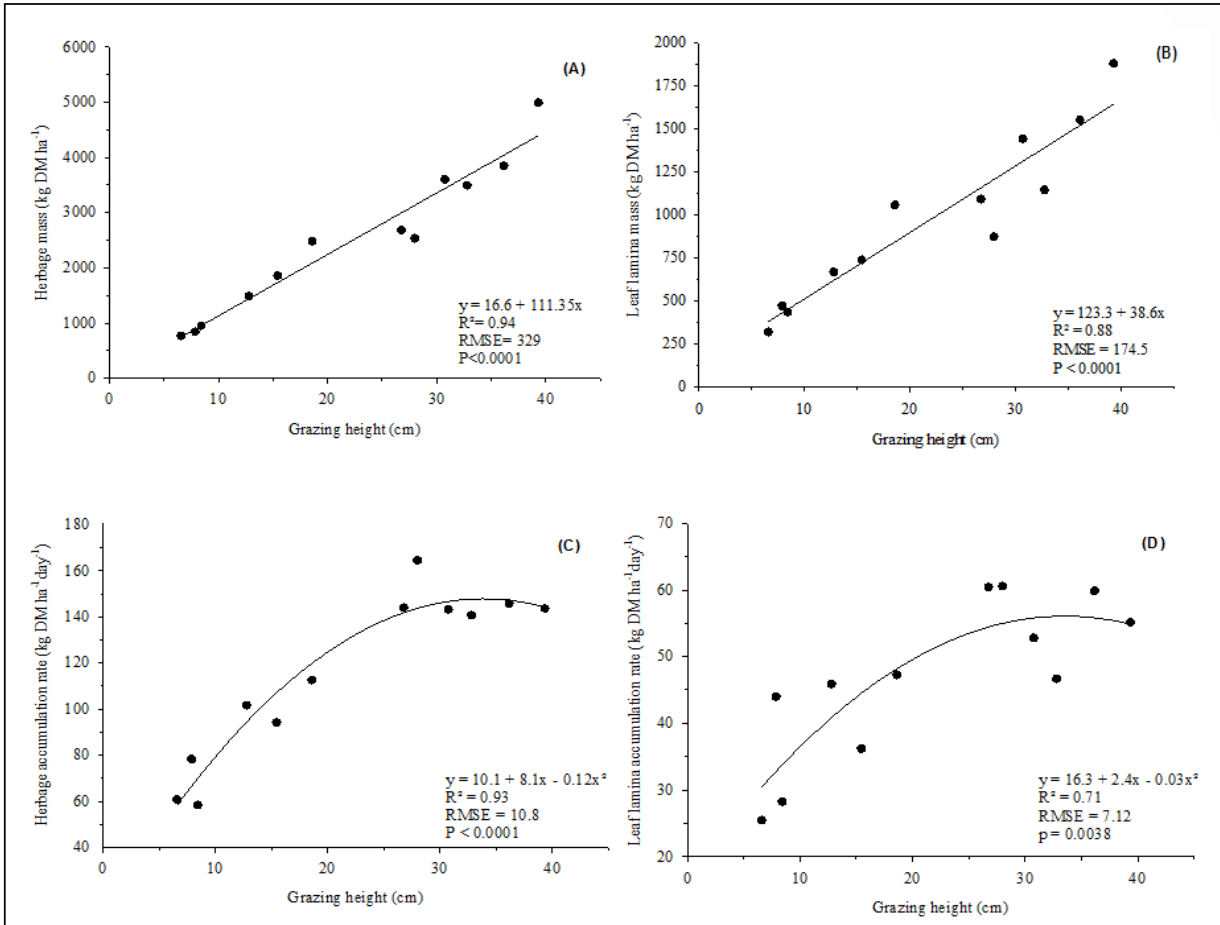

Figure 1 - Herbage (A) and leaf lamina (B) mass, herbage (C) and leaf lamina (D) accumulation rate of Alexandergrass pastures subjected to contrasting grazing heights by continuous stocking method in an integrated crop-livestock system.
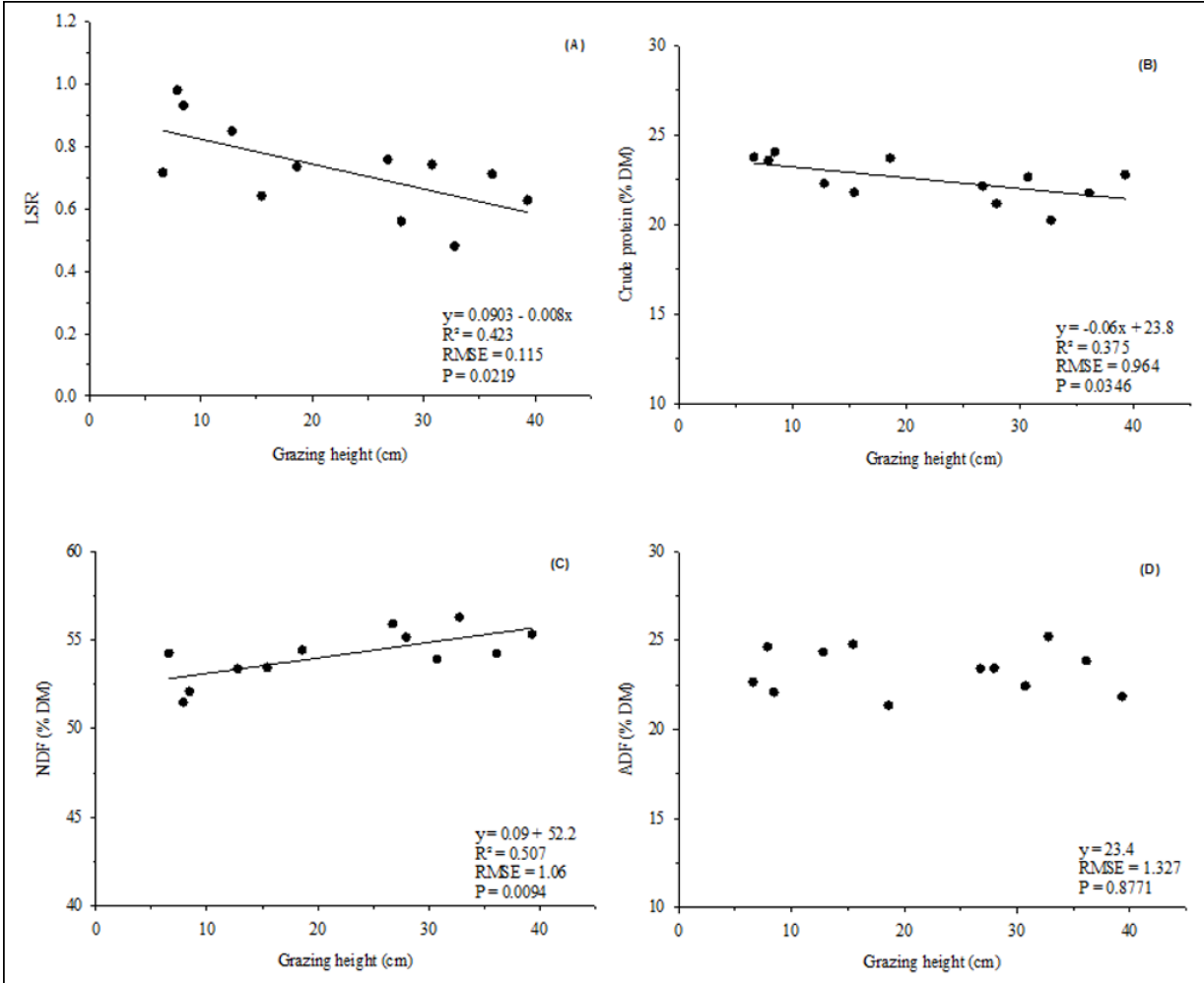

Figure 2 - Sward canopy leaf: stem ratio (A), and crude protein (B), neutral (C) and acid (D) detergent fiber contents of hand plucked herbage samples of Alexandergrass pastures subjected to contrasting grazing heights by continuous stocking method in an integrated crop-livestock system. 

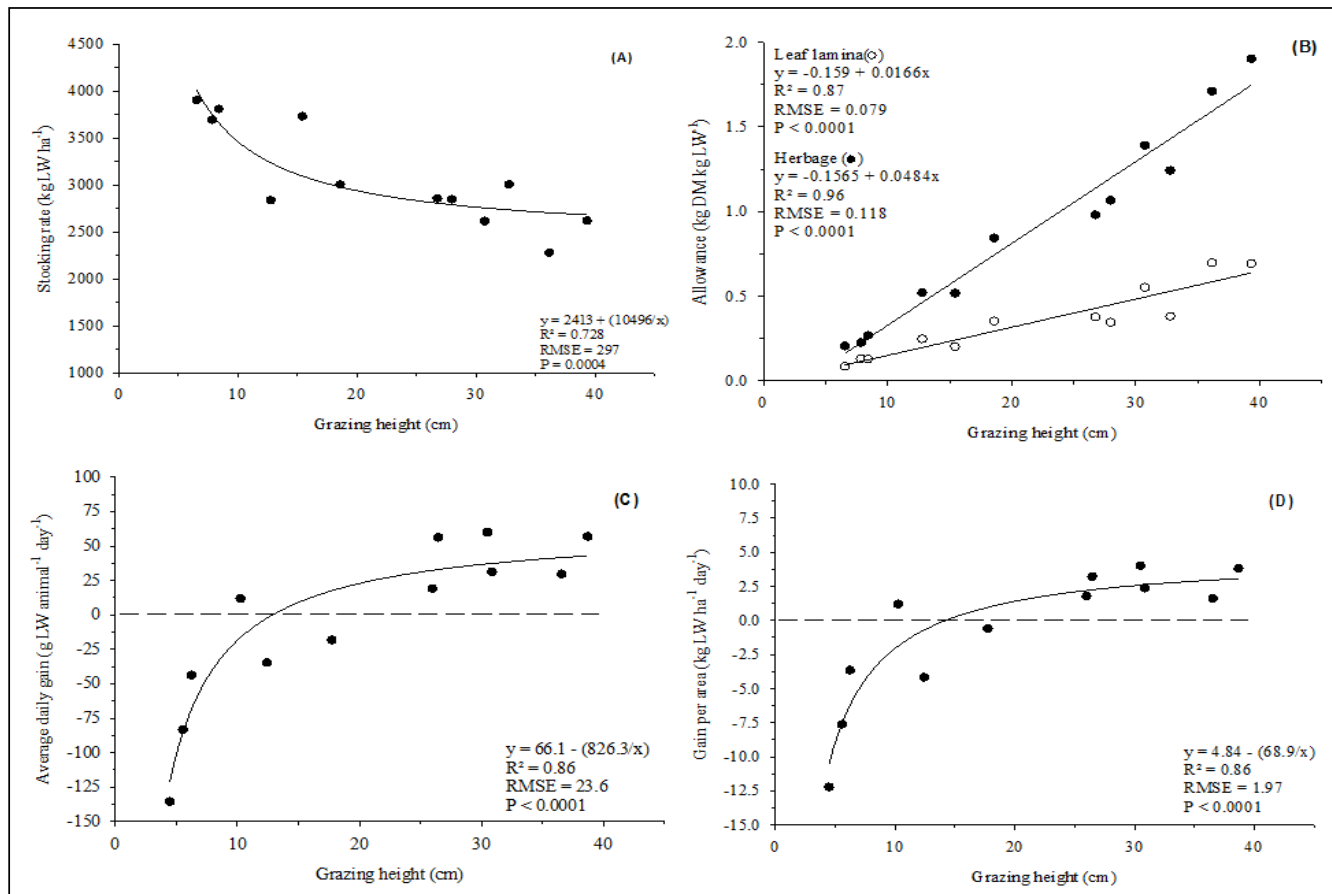

Figure 3 - Stocking rate (A), herbage and leaf lamina allowances (B), average daily gain (C) and live weight gain per area (D) of goats in Alexandergrass pastures subjected to contrasting grazing heights by continuous stocking method in an integrated crop-livestock system.

targets; ii) grazing heights between $30-40 \mathrm{~cm}$ did not affect daily intake, demanding less animals to do so; and iii) the apparent similarity in stocking rates between $30-40 \mathrm{~cm}$ (around $2700 \mathrm{~kg} \mathrm{LW} \mathrm{ha}{ }^{-1}$; Figure 3A) may have be a consequence of the same level of forage accumulation as already reported above (Figure $2 \mathrm{C}$ and 2D). In fact, experiments with Cynodon spp 'Tifton 85' (CARNEVALLI et al., 2001) and Brachiaria brizantha 'Marandu' (DA SILVA et al., 2013), reported greater and equivalent levels of forage intake and herbage production, as well as lower stocking rates, in a range of grazing heights (10-20 cm and 20-40 cm, respectively).

There were linear increments in herbage $(\mathrm{P}<0.0001)$ and leaf lamina $(\mathrm{P}<0.0001)$ allowances as grazing heights increased (Figure $3 \mathrm{~B}$ ). Such pattern of response was a consequence of both, the greater forage amount (Figure $1 \mathrm{~A}$ and $1 \mathrm{~B}$ ) and the similar stocking rate (Figure 3A), as already reported above. Forage allowance is a key-parameter in grazing livestock systems, since it determines the opportunity for feed selection, intake and; consequently, animal performance (SOLLENBERGER \& VANZANT, 2011). Despite the different methods to calculate forage allowance (SOLLENBERGER et al., 2005), small ruminants grazing tropical pastures seems to perform better with herbage allowances between 1.0-3.5 kg DM kg LW'-1 and/or leaf lamina allowances between $0.07-0.15 \mathrm{~kg}$ DM kg LW'-1 (DE SOUZA et al., 2014; CARNEVALLI et al., 2001). Thus, because both variables had a strong relationship with grazing height (Figure 3B), Alexandergrass pastures grazed by small ruminants should be maintained around $30-40 \mathrm{~cm}$ to ensure adequate levels of forage supply.

Average daily gain $(\mathrm{P}<0.0001)$ and gain per area $(\mathrm{P}<0.0001)$ were both affected by grazing heights and achieved an asymptotic upper plateau around 30-40 cm (Figure 3C and 3D). These results are in line with studies that also demonstrated increases in animal performance from adjustments in grazing height (CARNEVALLI et al., 2001; DA SILVA et al., 2013). A convergent point in explaining such results is the straight relationship between grazing height and variables highly correlated with both herbage intake and animal performance (e.g. herbage mass, leaf lamina allowance). In general, these relationships are curvilinear or asymptotic, since any increase in one of these variables is accompanied by increases in daily forage intake and animal performance, up to a point of relative stabilization or reduction (ROUQUETTE, 2016). Thus, the variations in animal performance reported in our study are due to the combined effect of variables correlated with grazing height (Table 1). Finally, because the pattern of responses observed 
Table 1 - Correlation coefficients $(\mathrm{r} ; \mathrm{n}=12)$ between some variables related to animal performance, forage availability, and grazing heights.

\begin{tabular}{|c|c|c|c|c|}
\hline Variable $^{*}$ & & $\mathrm{ADG}$ & Gain & GH \\
\hline \multirow{2}{*}{ HA } & $\mathrm{r}$ & 0.936 & 0.943 & 0.981 \\
\hline & $\mathrm{P}$ & $<0.0001$ & $<0.0001$ & $<0.0001$ \\
\hline \multirow{2}{*}{ LLA } & $\mathrm{r}$ & 0.945 & 0.964 & 0.933 \\
\hline & $\mathrm{P}$ & $<0.0001$ & $<0.0001$ & $<0.0001$ \\
\hline \multirow{2}{*}{ HM } & $\mathrm{r}$ & 0.908 & 0.911 & 0.972 \\
\hline & $\mathrm{P}$ & $<0.0001$ & $<0.0001$ & $<0.0001$ \\
\hline \multirow{2}{*}{ LLM } & $\mathrm{r}$ & 0.922 & 0.939 & 0.939 \\
\hline & $\mathrm{P}$ & $<0.0001$ & $<0.0001$ & $<0.0001$ \\
\hline
\end{tabular}

*Abbreviations: ADG: average daily gain; Gain: live weight gain per area; GH: grazing height; HA: herbage allowance; HM: herbage mass; LLA: leaf lamina allowance; LLM: leaf lamina mass.

here was similar to those reported with cattle grazing a quite similar forage species (e.g. Brachiaria brizantha 'Marandu'; FLORES et al., 2008; DA SILVA et al., 2013), there are evidences that the management targets recommended here could be similar for larger ruminants grazing Alexandergrass pastures under continuous stocking method.

\section{CONCLUSION}

Alexandergrass pastures under continuous stocking in ICLS should be maintained at $30-40 \mathrm{~cm}$ in order to improve animal performance and cover crop biomass production.

\section{ACKNOWLEDGEMENTS}

This study was financed in part by the Coordenação de Aperfeiçoamento de Pessoal de Nível Superior (CAPES) with the scholarship of the third author (PNPD/CAPES), and by the Instituto Agronômico do Paraná (IAPAR) with the technical support and the use of their facilities. The authors thank Dr. André Fischer Sbrissia and Dr. Paulo Gonçalves Duchini for valuable comments on early versions of the manuscript.

\section{DECLARATION OF CONFLICT OF INTERESTS}

The authors declare no conflict of interest. The founding sponsors had no role in the design of the study; in the collection, analyses, or interpretation of data; in the writing of the manuscript, and in the decision to publish the results.

\section{AUTHORS' CONTRIBUTIONS}

All authors contributed equally for the conception and writing of the manuscript. All authors critically revised the manuscript and approved of the final version.

\section{REFERENCES}

ADAMI, P.F. et al. Dynamic of a papuã pasture under two grazing intensities and two nitrogen levels. Revista Brasileira de Zootecnia, v.39, p.2569-2577, 2010. Available from: $<$ http://www. scielo.br/pdf/rbz/v39n12/a03v39n12.pdf >. Accessed: Sep. 3, 2018. doi: $10.1590 / \mathrm{S} 1516-35982010001200003$

BOLLINGER, A. et al. Taking stock of the Brazilian "zero-till revolution": A review of landmark research and farmers' practice. Advances in Agronomy, v.91, p.47-110, 2006. Available from: $<$ https://doi.org/10.1016/S0065-2113(06)91002-5>. Accessed: Jun. 8, 2019. doi: 10.1016/S0065-2113(06)91002-5.

CARNEVALLI, R.A. et al. Pasture and sheep performance on Tifton 85 (Cynodon spp) pastures under continuous stocking. Scientia Agricola, v.58, p.7-15, 2001. Available from: <http:// www.scielo.br/pdf/sa/v58n1/a02v58n1.pdf $>$. Accessed: Sep. 3, 2018. doi: 10.1590/S0103-90162001000100002.

DA SILVA, S.C. et al. Grazing behaviour, herbage intake and animal performance of beef cattle heifers on marandu palisade grass subjected to intensities of continuous stocking management. Journal of Agricultural Science, v.151, p.727-739, 2013. Available from: <https://doi.org/10.1017/S0021859612000858>. Accessed: Jun. 8, 2019. doi: 10.1017/S0021859612000858.

DA SILVA, S.C. et al. Ecophysiology of C4 forage grasses understanding plant growth for optimising their use and management. Agriculture, v.5, p.598-625, 2015. Available from: $<$ http://www. mdpi.com/2077-0472/5/3/598/htm>. Accessed: Sep. 3, 2018. doi: 10.3390/agriculture5030598.

DE MORAES, A. et al. Integrated crop-livestock systems in the Brazilian subtropics. European Journal of Agronomy, v.57, p. 4-9, 2014. Available from: <https://doi.org/10.1016/j.eja.2013.10.004>. Accessed: Sep. 3, 2018. doi: 10.1016/j.eja.2013.10.004.

DE SOUZA, J. et al. Green leaf allowance and dairy ewe performance grazing on tropical pasture. Journal of Animal Science, v.92, p. 27082715, 2014. Available from: <https://doi.org/10.2527/jas.2013-7238>. Accessed: Sep. 3, 2018. doi: 10.2527/jas.2013-7238. 
EUCLIDES, V.P.B. et al. Forage nutritive value and animal production in Brachiaria brizantha pastures. Pesquisa Agropecuária Brasileira, v.44, p.98-106, 2009. Available from: $<$ http://www.scielo.br/pdf/pab/v44n1/14.pdf $>$. Accessed: Sep. 3, 2018. doi: 10.1590/S0100-204X2009000100014.

FAO - FOOD AND AGRICULTURE ORGANIZATION International soil classification system for naming soils and creating legends for soil maps (world soil resources reports n.106). Rome: FAO, 2014.192p.

FLORES, R.S. et al. Animal performance, forage yield and structural characteristics in the palisadegrass cvs. marandu and xaraés submitted to grazing intensities. Revista Brasileira de Zootecnia, v.37, p.1355-1365, 2008. Available from: <http://www. scielo.br/pdf/rbzv37n8/v37n8a04.pdf>. Accessed: Jun. 8, 2019. doi: 10.1590/S1516-35982008000800004.

HODGSON, J. Grazing management: science into practice. New York: Longman Scientific and Technical, 1990. 190p.

KUNRATH, T.R. et al. Management targets for continuously stocked mixed oat $\mathrm{x}$ annual ryegrass pasture in a no-till integrated croplivestock system. European Journal of Agronomy, v.57, p.71-76, 2014. Available from: <http://doi.org/10.1016/j.eja.2013.09.013>. Accessed: Jun. 8, 2019. doi: 10.1016/j.eja.2013.09.013.

McCARTHY, B. et al. The multi-year cumulative effects of alternative stocking rate and grazing management practices on pasture productivity and utilization efficiency. Journal of Dairy Science, v.99, p.3784-3797, 2018. Available from: <http:// doi.org/10.3168/jds.2015-9763>. Accessed: Sep. 3, 2018. doi: $10.3168 /$ jds.2015-9763.

MARTINS, J.D. et al. Animal production on Alexandergrass (Brachiaria plantaginea (Link) Hitchc) submitted to nitrogen levels. Ciência Rural, v.30, p.887-892, 2000. Available from: $<$ http://www.scielo.br/pdf/cr/v30n5/a25v30n5.pdf $>$. Accessed: Sep. 3, 2018. doi: 10.1590/S0103-84782000000500025.

NEGRINI, M. et al. Forage intake and performance of heifers fed rice bran on Alexandergrass pasture. Arquivo Brasileiro de Medicina
Veterinária e Zootecnia, v.70, p.1577-1585, 2018. Available from: $<$ http://doi.org/10.1590/1678-4162-9701>. Accessed: Jun. 8, 2019. doi: $10.1590 / 1678-4162-9701$.

SYSTAT SOFTWARE. SigmaPlot 11.0: User's guide. Richmond: Systat Software, 2002.

SBRISSIA, A.F. et al. Tillering dynamics in palisadegrass swards continuously stocked by cattle. Plant Ecology, v.206 p.349-359, 2010. Available from: <https://doi.org/10.1007/ s11258-009-9647-7>. Accessed: Sep. 3, 2018. doi: 10.1007/ s11258-009-9647-7.

RESTLE, J. et al. Animal performance in summer grasses pastures. Revista Brasileira de Zootecnia, v.31, p.14911500, 2002. Available from: <http://www.scielo.br/pdf/rbz/ v31n3s0/13106.pdf>. Accessed: Sep. 3, 2018. doi: 10.1590/S151635982002000600021 .

ROUQUETTE, F.M. Invited review: The roles of forage management, forage quality, and forage allowance in grazing research. The Professional Animal Scientist, v. 32 p.10-18, 2016. Available from: <https://doi.org/10.15232/ pas.2015-01408>. Accessed: Sep. 3. 2018. doi: 10.15232/ pas.2015-01408.

SILVA, M.G. et al. Dynamics of the association of Alexandergrass and capim-de-raiz on deferred grazing. Revista Brasileira de Zootecnia, v.40, p.2340-2346, 2011. Available from: $<$ http://www. scielo.br/pdf/rbz/v40n11/09.pdf $>$. Accessed: Jun. 8, 2019. doi: 10.1590/S1516-35982011001100009.

SOLLENBERGER, L.E. et al. Reporting forage allowance in grazing experiments. Crop Science, v.45, p.896-900, 2005. Available from: <https://doi.org/10.2135/cropsci2004.0216>. Accessed: Sep. 3, 2018. doi: 10.2135/cropsci2004.0216.

SOLLENBERGER, L.E.; VANZANT, E.S. Interrelationships among forage nutritive value and quantity and individual animal performance. Crop Science, v.51, p.420-432, 2011. Available from: <https://doi.org/10.2135/cropsci2010.07.0408>. Accessed: Sep. 3, 2018. doi: 10.2135/cropsci2010.07.0408. 